\title{
How diverse is the chemistry and plant origin of Brazilian propolis?
}

\author{
Antonio SAlatino $^{1}$, Maria Luiza Faria SAlatino ${ }^{1}$, and Giuseppina Negri ${ }^{1}$ \\ ${ }^{1}$ Department of Botany, Institute of Biosciences, University of São Paulo, Rua do Matão 277, São Paulo, SP 05508-090, \\ Brazil
}

Received 21 August 2020 - Revised 6 July 2021 - Accepted 12 August 2021

\begin{abstract}
Propolis is a honey bee product containing chiefly beeswax and resins originated from plant buds or exudates. Propolis resin exerts a diversity of biological activities, such as antitumoral, anti-inflammatory, antimicrobial, and defense of the hive against pathogens. Chemical standardization and identification of botanical sources is crucial for characterization of propolis. Types of Brazilian propolis are characteristic of geographical regions and respective biomes, such as savannas (Cerrado), mangroves, dry forest (Caatinga), rain forests (Amazon, Atlantic, and Interior forests), altitudinal fields ("Campos Rupestres"), Pantanal, and Araucaria forests. Despite the wide diversity of Brazilian biomes and flora, relatively few types of Brazilian propolis and corresponding resin plant sources have been reported. Factors accounting for the restricted number of known types of Brazilian propolis and plant sources are tentatively pointed out. Among them, the paper discusses constraints that honey bees must overcome to collect plant exudates, including the characteristics of the lappingchewing mouthpart of honey bee, which limit their possibilities to cut and chew plant tissues, as well as chemical requirements that plant resins must fulfil, involving antimicrobial activity of its constituents and innocuity to the insects. Although much still needs to be done toward a more comprehensive picture of Brazilian propolis types and corresponding plant origins, the prospects indicate that the actual diversity of plant sources of honey bee propolis will remain relatively low.
\end{abstract}

\section{artepillin C / flavonoids / triterpenoids / baccharis dracunculifolia / apis mellifera}

\section{INTRODUCTION}

Propolis (bee glue) is a resinous product from hives of honey bees (Apis mellifera, Apidae). Propolis smell, texture, and color vary widely. Some propolis types have resinous smell, others are inodorous. Some are stiff and friable, others sticky and moldable. Propolis color may be light cream, green, red, brown, or black. Medicinal uses of propolis date back to antiquity (Ghisalberti 1979; Kuropatnicki

Corresponding author: A. Salatino, asalatin@ib.usp.br

Handling Editor: Peter Rosenkranz et al. 2013). The medicinal relevance of propolis declined in the Middle Ages, but a resurgence took place in the Renaissance with the theory of adfontes. Propolis is produced also by other groups of bees, such as the stingless bees Meliponini. Reviews are available about composition and biological activity of Meliponini propolis (Bankova and Popova 2007; Lavinas et al. 2019). The present paper deals almost exclusively with propolis from Apis mellifera.

The first investigations about biological activity of propolis dealt with bacteriostatic activity. They date from the late 1940 s by Russian and French researchers (Villanueva et al. 1964). The interest in propolis chemistry and its medicinal properties gained momentum 
in the second half of the last century and has increased steadily to date. Before the 1990s, publication of papers about propolis was occasional. Since then the number of publications has escalated, including successive reviews about chemistry, botanical origin, and biological properties of propolis (Marcucci 1995; Bankova 2005; Salatino et al. 2011; Sforcin 2016). Propolis and its isolated constituents have been shown to exert antimicrobial and antioxidant activity. A wide spectrum of therapeutic applications has been ascribed to propolis, such as anti-inflammatory, antitumoral, anti-HIV, anti-ulcer, hepatoprotective, immunomodulatory, and wound healing (Sforcin 2016; Zabaiou et al. 2017; Anjum et al. 2019). A randomized and controlled clinical trial, involving 124 hospitalized adult patients with COVID-19, revealed that adjunct treatment with standardized Brazilian green propolis extract significantly reduced the hospital stay post-intervention (Silveira et al. 2021). Most literature about propolis date from the last 30 years. Thus, overall, propolis research may be assumed as a relatively recent scientific topic. A diversity of products containing propolis is available in the market, such as propolis-enriched honey, propolis candies, alcoholic extracts, mouth and throat sprays, soaps, toothpastes, and skin creams.
Propolis contains mainly beeswax and plant resins, as well as minor constituents such as pollen, amino acids, and minerals. The biological activity of propolis derives from constituents of its plant resin, most of which worldwide are phenolic substances. The first propolis type studied with scientific procedures was the poplar propolis, from temperate regions. It contains exudates of apical buds of Populus species (poplar trees, family Salicaceae), such as P. nigra, P. tremula, and Populus $\times$ canadensis (Bankova 2005; Bertrams et al. 2013; Popova et al. 2017). Poplar propolis contains chiefly flavonoids with no oxygenation on the B ring. An example is chrysin (a flavone, Fig. 1A), the first flavonoid identified in propolis (Jaubert 1926). Other examples are galangin (flavonol; Fig. 1B) and pinocembrin (flavanone, Fig. 1C), which also are among the first flavonoids to be isolated from propolis (Villanueva et al. 1964, 1970). Other important constituents of poplar propolis are caffeic acid esters, such as CAPE (caffeic acid phenethyl ester, Fig. 1D). In North America, propolis may derive from P. balsamifera and P. deltoides (Wilson et al. 2013). In the south of Brazil, as well as in Argentina and Uruguay, some propolis types derive from P. alba (Park et al. 2002). Plants from other genera may be sources of resin for temperate propolis. Examples are (a) Betula verrucosa

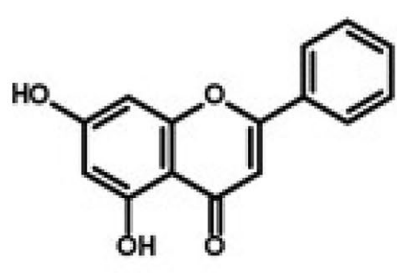

A. Chrysin

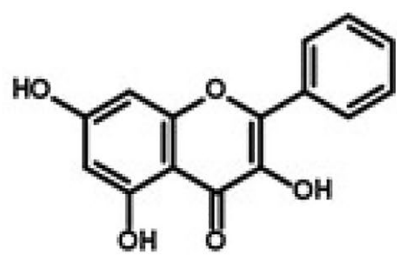

B. Galangin

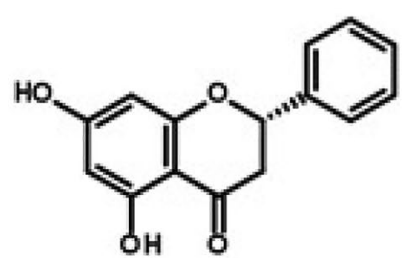

C. Pinocembrin

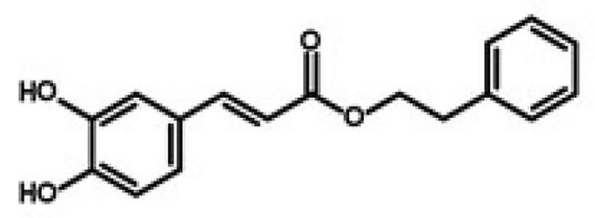

\section{Caffeic acid phenethyl ester}

(CAPE)

Figure 1. Major constituents of propolis from temperate countries, derived from species of Populus (Salicaceae). 
(Betulaceae; Popova et al. 2013), Russia; (b) Zuccagnia punctata (Leguminosae, Faboideae; Salas et al. 2016) and Larrea nitida (Zygophyllaceae; Aguero et al. 2011), Argentina; (c) Dalbergia sp. (Leguminosae, Faboideae; Awale et al. 2005), Nepal; and (d) species of Ferula (Apiaceae) are probable sources of mono- and sesquiterpenes isolated from Iranian propolis (Trusheva et al. 2010). Plant species from several genera are sources of propolis resin in subtropical areas of the world. Examples are (a) Acacia paradoxa (Leguminosae, Mimosoideae; Tran et al. 2012) and Lepidosperma sp. (Cyperaceae; Duke et al. 2017), Australia, and (b) Macaranga tanarius (Euphorbiaceae; Kumazawa et al. 2008), Okinawa and Taiwan. Examples of propolis types in tropical areas are Brazilian green (Salatino et al. 2005) and red propolis (Silva et al. 2008), as well as Venezuelan and Cuban propolis (Bankova et al. 2006; Trusheva et al. 2004; Cuesta-Rubio et al. 2002).

Propolis was previously regarded an undesirable by-product of the hive. From the 1980s to now, propolis has gradually turned out the main source of income for many commercial apiaries. China, Brazil, and Russia are the world top producers of propolis (Bees for Development 2016). Presently, a highly active domestic and international trade of Brazilian propolis is operative. Propolis market size in Japan was US\$ 3 billion in $2009,80 \%$ of it derived from Brazilian propolis (Toreti et al. 2013).

\section{BRAZILIAN PROPOLIS}

\subsection{Biomes, types, and composition}

The botanical source of resin is a prime characteristic of a propolis type. While most propolis from temperate regions are produced from cultivated poplar species, tropical propolis derives mostly from plants growing in the wild. Because plant species are generally characteristic of a biome, it is possible to associate types of Brazilian propolis with their biomes (Fig. 2, Table 1).

Climate and geography are key factors determining the characteristics of biomes and their flora. Brazilian wide territorial expanse and climatic variability account for the diversity of biomes of the country (Fig. 2). Other factors are also relevant, such as pluviometry, altitude, and soil physicochemical characteristics. High pluviometry characterizes Amazonian, Atlantic, and Interior forests, with luxurious vegetation, comprising trees, epiphytes, and lianas. On the contrary, long periods of drought select for dry habitats, such as the Caatinga, an exclusive semiarid Brazilian biome, dominated by spiny trees and shrubs, euphorbs, and cacti (Santos et al. 2014). The Cerrado biome covers one-third of the Brazilian territory, in the southeast, central, and central-west Brazil. They are savannas with marked dry and rainy seasons, characterized by sparse trees, shrubs, and a continuous stratum of herbaceous plants, growing on acidic and nutritionally poor soils (Salatino 1993; Grace et al. 2006; Souza et al. 2015). "Campos rupestres" are mostly herbaceous and shrubby savannas at altitudes above $1000 \mathrm{~m}$, amidst expanses dominated by Cerrado (Fig. 2). Their vegetation comprises heliophilous and often xerophytic plants (Alves et al. 2014), growing on sandy or rocky soils. The Pantanal is the widest wetland ecosystem in the world. It is a periodically flooded biome in the state of Mato Grosso (central-west Brazil) (Arieira et al. 2011). The south part of Brazil contains areas of Atlantic Forest on the coast and forests of Araucaria angustifolia (a conifer tree species) (Dumig et al. 2008), as well as the Pampas, a grassland biome in the state of Rio Grande do Sul, in the extreme southern Brazil. From the south of Brazil to Amapá (the most northern state of the country), mangroves are common on the coast of the country, wherever river fresh water meets sea salt water (Fig. 2).

The most important Brazilian propolis is the green type. It is produced, predominantly in the southeast of the country, in areas of Cerrado, chiefly in the state of Minas Gerais (Fig. 2, A). It derives from apical buds and young leaves of Baccharis dracunculifolia ("alecrim-docampo"; Asteraceae; Table 1). Honey bees cut apical young tissues of the plant in small pieces, gather them inside corbiculae on their hind legs, and take them to the hive (Teixeira et al. 2005). 


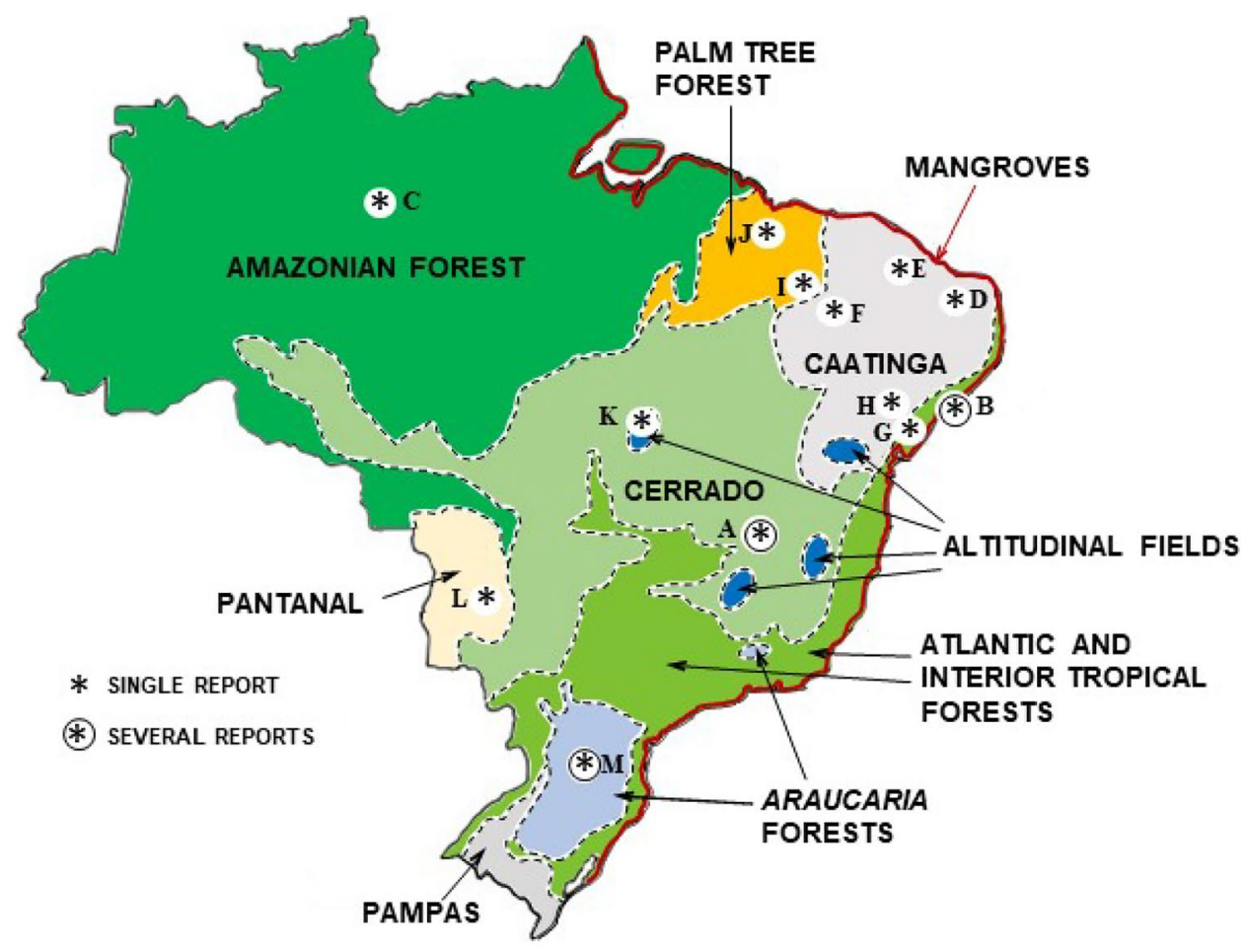

Figure 2. Brazilian biomes and sites (asterisks) of production of propolis types. (A) Green propolis; many localities in the southeast, Central and Western Brazil, in areas of Cerrado. (B) Red propolis; northeast, in mangroves. (C) Black propolis, in a clear of Amazonian forest, close to Manaus (state of Amazonas). (D) Green propolis of Caatinga, in Mossoró (state of Rio Grande do Norte). (E, F) Dark propolis produced in the Caatinga, state of Ceará (northeast). (G) Brown propolis in the Atlantic forest of the state of Bahia (northeast); (H) Brown propolis from Caatinga, in the state of Bahia (northeast). (I, J) Dark propolis produced in areas of palm tree forests in the state of Piauí (northeast). (K) Dark propolis produced in "Campo Rupestre" in the state of Goiás (Central Brazil). (L) Yellow propolis from the Pantanal ecosystem, state of Mato Grosso do Sul (Central-West Brazil). (M) Brown propolis from several areas of Araucaria forest in the south. Map with biome limits based on https://br.pinterest.com/pin/821484788254686886/ (accessed August 20, 2020).

Because this plant material contains chlorophyll, B. dracunculifolia propolis has a green hue. However, propolis with similar composition have been reported for regions on the borders of the Cerrado dominium, e.g., in southern Brazil (FernandesSilva et al. 2013), in the state of Bahia (southern northeast Brazil; Righi et al. 2013), and in sites outside Brazil, e.g., in Bolivia (Nina et al. 2016) (Table 1). The main constituents of Brazilian green propolis are prenylated phenylpropanoids (Fig. 3A-D) and chlorogenic acids (Fig. 3E) (Salatino et al. 2005; Moise and Bobiş 2020). Flavonoids (e.g., kaempferide; Fig. 3F) are also constituents of green propolis, as well as condensed tannins (Mayworm et al. 2014). From the point of view of biological properties, the phenylpropanoid artepillin C (Fig. 3A) of Brazilian green propolis stands as one of the most investigated propolis constituents (Beserra et al. 2020).

Over the last 15 years, Brazilian red propolis has turned out an important commercial product in the domestic and international trades. It is produced on mangroves, on the littoral of the northeastern states (Fig. 2, B), from a red exudate of stems of Dalbergia ecastaphyllum (Leguminosae, Faboideae; Table 1). In several papers from propolis literature, the plant species has been referred to as Dalbergia ecastophyllum, an 


\section{Table 1}

Selected types of Brazilian propolis and respective biomes, main chemical constituents and plant sources. For biome geographic coverages, see Fig. 2

\begin{tabular}{|c|c|c|c|c|}
\hline Type & Biome & Chemical profile & Plant origin & References \\
\hline Amazonian black & Amazonian forest & $\begin{array}{c}\text { Polyisoprenylated } \\
\text { benzophenones }\end{array}$ & Clusia sp. & Ishida et al. (2011) \\
\hline Brown & Araucaria forest & Varied & $\begin{array}{l}\text { Araucaria, Populus, } \\
\text { other native and culti- } \\
\text { vated plant species }\end{array}$ & $\begin{array}{l}\text { Koo et al. (1999); } \\
\text { Adelman et al. } \\
\text { (2007) }\end{array}$ \\
\hline Dark & Atlantic Forest & Xanthones, steroids & Symphonia globulifera & Xavier et al. (2017) \\
\hline Dark & "Campos rupestres" & Prenylated flavonols & Velloziaceae (?) & Righi et al. (2013) \\
\hline Green & Cerrado & $\begin{array}{l}\text { Prenylated phenylpro- } \\
\text { panoids, triterpenoids }\end{array}$ & $\begin{array}{l}\text { Baccharis dracun- } \\
\text { culifolia, Vernonia } \\
\text { rubriramea }\end{array}$ & $\begin{array}{l}\text { Freire (2000); Salatino } \\
\text { et al. (2005); Righi } \\
\text { et al. (2013) }\end{array}$ \\
\hline Green & Caatinga & Chalcones, flavonols & Mimosa tenuiflora & Ferreira et al. (2017) \\
\hline Red & Mangrove & $\begin{array}{l}\text { Chalcones, isoflavo- } \\
\text { noids, prenylated } \\
\text { benzophenones }\end{array}$ & $\begin{array}{l}\text { Dalbergia ecastaphyl- } \\
\text { lum, Symphonia } \\
\text { globuliera }\end{array}$ & $\begin{array}{l}\text { Daugsch et al. (2008); } \\
\text { Silva et al. (2008); } \\
\text { Ccana-Ccapatina } \\
\text { et al. (2020) }\end{array}$ \\
\hline Yellow & Pantanal & Steroids, triterpenoids & Undetermined & $\begin{array}{l}\text { Machado et al. } \\
\text { (2016) }\end{array}$ \\
\hline
\end{tabular}

illegitimate name (Salatino and Salatino 2018). Chief constituents of red propolis are metabolites typical of Leguminosae plants, chiefly isoflavonoids, in addition to chalcones (e.g., isoliquiritigenin, Fig. 4A) and neoflavonoids (e.g., dalbergin, Fig. 4B). In Leguminosae, isoflavonoids are restricted to the subfamily Faboideae (Veitch 2007). Classes of isoflavonoids from red propolis are isoflavones (e.g., formononetin and biochanin A; Fig. 4C and D, respectively), isoflavans (e.g., vestitol; Fig. 4E), and pterocarpans (e.g., medicarpin; Fig. 4F) (Daugsch et al. 2008; Silva et al. 2008; Righi et al. 2013; Moise and Bobiş 2020; Aldana-Mejia et al. 2021). Interesting flavonoid dimers with potent cytotoxic activity against cancer cells, designated propolols, propolonones, and propolones (e.g., propolone D; Fig. 4G), have been reported for Brazilian red propolis (Banzato et al. 2020). These substances, new to science, evidence the contribution of propolis research to plant chemistry: they are examples, among many others (Salatino et al. 2011), of plant constituents detected for the first time in propolis. Such dimers have structural resemblance with retusapurpurins (Fig. $4 \mathrm{H}$ ), pigments from mangrove propolis with intense red color, which are probably derived biosynthetically from chalcones and isoflavans. Polyprenylated benzophenones have been detected in red propolis, the plant source having been recognized as Symphonia globulifera (CcanaCcapatina et al. 2020), a species occurring not in mangroves, but in the Atlantic Forest. The two biomes occur side by side on coastal Brazilian regions (Fig. 2).

For both Brazilian green and red propolis, chemical markers have been established. The widely known chemical marker for Brazilian green propolis is artepillin C (3,5-diprenyl$p$-coumaric acid, Fig. 3A) (Matsuda and de Almeida-Muradian 2008). A second marker has been proposed, namely, the allyl ester of 3-prenyl-cinnamic acid (Fig. 3B) (Nascimento et al. 2008; Mayworm et al. 2015). Chemical markers of Brazilian red propolis are isoflavones, e.g., formononetin (Fig. 4C) and biochanin A (Fig. 4D) (López et al. 2014). Aldana-Mejia et al. (2021) established an HPLC-UV method 


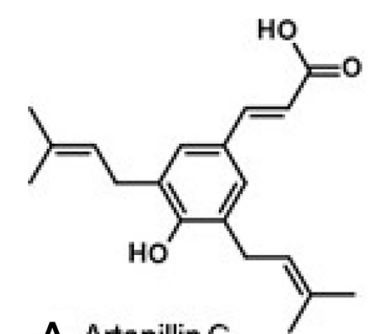

A. Artepillin C<smiles>CC(C)=CCc1cc(/C=C/C(=O)O)ccc1OC(=O)CCc1ccccc1</smiles>

D. Baccharin

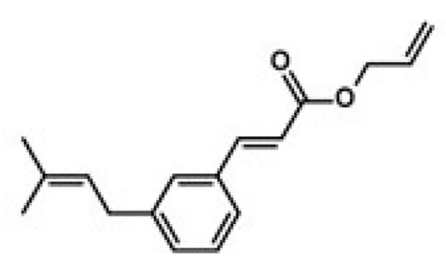

B. 3-Prenyl cinnamic acid allyl ester

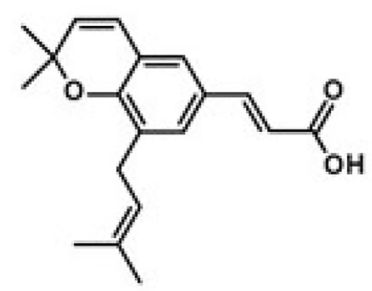

C. 2,2-Dimethyl-8prenylchromene<smiles>O=C(/C=C/c1ccc(O)c(O)c1)OC1C[C@](O)(C(=O)O)C[C@@H](OC(=O)/C=C/c2ccc(O)c(O)c2)[C@H]1O</smiles>

E. 3,3,-Dicaffeoylquinic acid.

An example of chlorogenic acid<smiles>COc1ccc(-c2oc3cc(O)c(OC)c(O)c3c(=O)c2O)cc1</smiles>

F. Kaempferide

Figure 3. Constituents of Brazilian green propolis derived from Baccharis dracunculifolia (Asteraceae).

involving nine markers of Brazilian red propolis, aiming the analysis and standardization of products derived from this propolis type.

A diversity of other types of Brazilian propolis has been reported. Some are produced commercially, although in scale far below the southeastern green and the northeastern red propolis. A black propolis is produced in a location near Manaus (north Brazil, Fig. 2, C; Table 1), in a clear inside the Amazonian Forest. It contains polyisoprenylated benzophenones, e.g., xanthochymol (Fig. 5A) and 7-epi-nemorosone (Fig. 5B) (Ishida et al. 2011), with a chemical profile resembling Venezuelan and Cuban propolis, both derived from exudates of flowers of $\mathrm{Clu}$ sia species (Clusiaceae; Tomas-Barberán et al. 1993). A new type of green propolis is produced in the state of Rio Grande do Norte (northeast
Brazil), in Caatinga areas (Fig. 2, D), characterized by high flavonoid content and antioxidant activity. Among its flavonoid constituents predominate flavonols, e.g., dimethoxyquercetin (Fig. 6A) and chalcones (e.g., dihydroxydimethoxychalcone; Fig. 6B). The Caatinga green propolis derives from vegetative buds of Mimosa tenuiflora (Leguminosae, Mimosoideae; Ferreira et al. 2017; Table 1), locally known as "jurema-preta," whose bark is used in entheogen rituals from a mingling of African and Amerindian cultures.

A dark propolis from the municipality of Alto Santo, in the Caatinga of the state of Ceará (northeast Brazil, Fig. 2, E), contains flavonoids (e.g., acacetin; Fig. 7A) and triterpenoids, such as canaric acid (Fig. 7B) and germanicone (Fig. 7C) (de Albuquerque et al. 2007). A 
<smiles>O=C(/C=C/c1ccc(O)cc1)c1ccc(O)cc1O</smiles>

A. Isoliquiritigenin<smiles>COc1cc2oc(=O)cc(-c3ccccc3)c2cc1O</smiles>

B. Dalbergin<smiles>COc1ccc(-c2coc3cc(O)ccc3c2=O)cc1</smiles>

C. Formononetin<smiles>COc1ccc(-c2coc3cc(O)cc(O)c3c2=O)cc1</smiles>

D. Biochanin a<smiles>COc1ccc(C2COc3cc(O)ccc3C2)c(O)c1</smiles>

E. Vestitol<smiles>Oc1ccc2c(c1)OC[C@H]1c3ccc(O)cc3O[C@H]21</smiles>

F. Medicarpin
G. Propolone D<smiles>COc1ccc2c(Cc3cc(C4COc5cc(O)ccc5C4)c(O)cc3O)c(-c3ccc(O)cc3O)oc2c1</smiles>

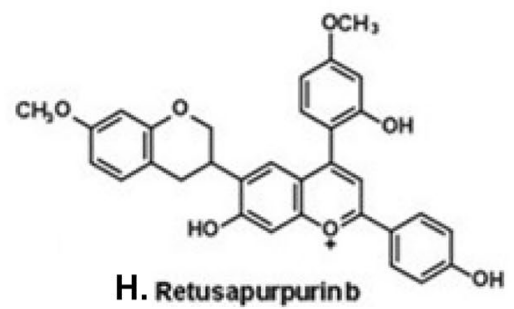

H. Retusapurpurin b

Figure 4. Constituents of Brazilian red propolis.

different dark propolis is produced in the municipality of Salitre (Fig. 2, F), also in the state of Ceará, but in an area at higher altitude $(650 \mathrm{~m})$, dominated by a mesophytic forest habitat. Salitre propolis contains chiefly flavonoids, including chalcones and methylated flavonols (FernandesSilva et al. 2019), resembling the composition of the green propolis of Rio Grande do Norte.
The xanthone ananixanthone (Fig. 8A) and the steroid sitosteryl cinnamate (Fig. 8B) were isolated from a brown propolis from an Atlantic Forest region, in the municipality of Entre Rios, located in the state of Bahia (Northeast Brazil; Fig. 2, G; Table 1) (dos Santos et al. 2017). Ananixanthone is a constituent of the bark of Symphonia glandulifera (Clusiaceae), a<smiles>C=C(C)CCC(CC12CC(CC=C(C)C)C(CC=C(C)C)(C(=O)C1(CC=C(C)C)C(C)(C)C)C(O)C(C(=O)c1ccc(O)c(O)c1)C2=O)C(=O)O</smiles><smiles>CC(C)=CCC1=C(O)C2(C(=O)c3ccccc3)C(=O)C(CC=C(C)C)(CC(CC=C(C)C)C(C)(C)C)C(=O)C2(CC=C(C)C)C1=O</smiles>

B. 7-epi-Nemorosone

Figure 5. Polyprenylated benzophenones from black propolis from a clear in the Amazonian forest near Manaus (north Brazil). 
<smiles>COc1cc(O)c2c(=O)c(OC)c(-c3ccc(O)c(O)c3)oc2c1</smiles>

A.Quercetin 3,7-dimethyl ether<smiles>COc1ccc(/C=C/C(=O)c2c(O)cc(OC)cc2O)cc1</smiles>

B.Dihydroxy-dimethoxy chalcone

Figure 6. Flavonoid constituents of green propolis from the Caatinga (northeast Brazil), derived from Mimosa tenuiflora (Leguminosae, Mimosoideae).

probable source of the resin of the Entre Rios propolis (Table 1). This same species was mentioned above as source of polyprenylated benzophenones of mangrove red propolis. A dark propolis is produced also in Bahia but this time in two close localities of the Caatinga (Fig. 2, H). This propolis contains phenylpropanoids (e.g., artepillin C), flavonoids (e.g., rutin, quercetin, kaempferol, luteolin, formononetin), and volatile compounds (alcohols, aldehydes, ketones, monoterpenes, and sesquiterpenes) (Xavier et al. 2017). No plant source has been assigned to this propolis.

Dark propolis is produced in the state of Piauí (northeast Brazil), in regions dominated by palm tree forest. A propolis from the municipality of Picos (Fig. 2, I) yielded chiefly triterpenoids, such as amyrinone (Fig. 9A) and flavonols, such as isorhamnetin (Fig. 9B) (Righi et al. 2013). A sample from Teresina (state of Piauí; Fig. 2, J) yielded chiefly cycloartane steroids (da Silva et al. 2005), such as mangiferolic acid (Fig. 9C), a substance from mango tree plants (Mangifera indica, Anacardiaceae), but known also from other plant sources (e.g., Illicium difengpi; Huang et al. 1997).

A dark propolis produced in the region of Pirenópolis, in the state of Goiás (West-Central Brazil; Fig. 2, K), contains several prenylated flavonols, e.g., prenylmethoxy quercetin and prenylmethoxy kaempferol (Righi et al. 2011). Pirenópolis is a city surrounded by altitudinal fields ("Campos Rupestres"), at altitudes above $1000 \mathrm{~m}$. It is suggestive that prenylmethoxy flavonols have been isolated from leaf surfaces of Vellozia (Velloziaceae) (Harborne et al. 1993), a plant genus typical of Brazilian "Campos Rupestres" (Franceschinelli et al. 2006).

Yellow propolis occurs in the state of Mato Grosso do Sul (Brazilian West-Central region), in areas of the Pantanal biome (Fig. 2, L). This type of propolis contains little or no phenolic compounds. Instead, a high variety of triterpenoids and steroids were isolated as main constituents, including ursadienol, lupenone, oleanone, and betulin (Fig. 10A-D, respectively). Steroids were also isolated from yellow propolis, e.g., lanosterol (Fig. 10E) and a derivative of
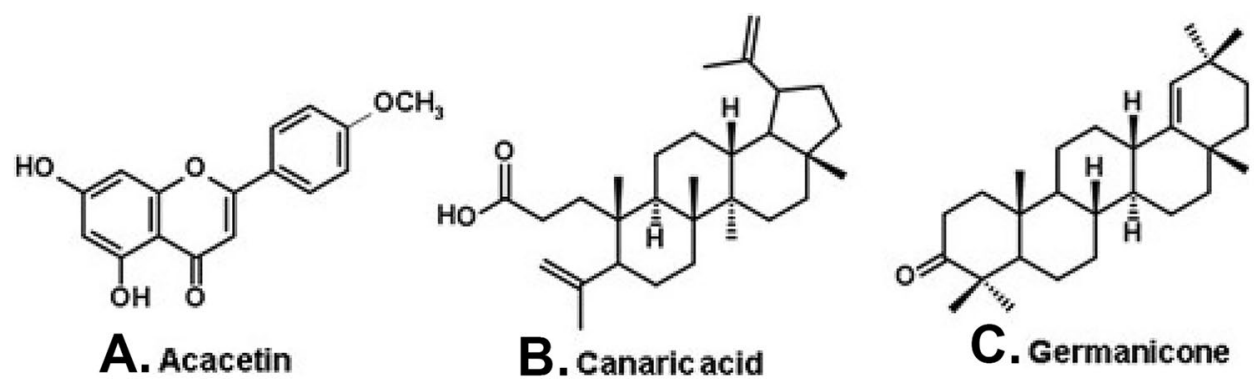

Figure 7. Constituents of a dark propolis produced in the state of Ceará (northeast Brazil). 


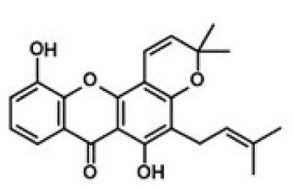

A. Ananixanthone

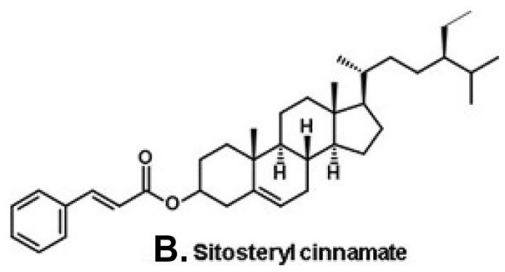

Figure 8. A xanthone and a steroid of a dark propolis from the Atlantic forest region in the state of Bahia (northeast Brazil).

cycloartenol (Fig. 10F; Machado et al. 2016). The plant origin of yellow propolis is unknown.

Propolis with brown color is produced in several areas of the Brazilian territory. For example, brown propolis produced in the municipality of Cabo Verde (state of Minas Gerais, southeast Brazil) contains volatile oil with antimicrobial and leishmanicidal activities; the oil was shown to contain chiefly mono- and sesquiterpenes, in addition to $\gamma$-palmitolactone (Ribeiro et al. 2020). However, the designation "brown propolis" refers mostly to products from the Brazilian south region (states of Paraná, Santa Catarina and Rio Grande do Sul), in areas with climate ranging from subtropical to temperate, dominated by Araucaria forests (Fig. 2, M). Distinct chemical profiles have been reported for southern brown propolis. Compounds characteristic of B. dracunculifolia, e.g., artepillin C (Fig. 3A), have been detected in brown propolis, but its botanical origin is more complex. For example, luteolin-5-O-methyl ether (Fig. 11A), a compound so far with unknown plant origin, has been detected (Fernandes-Silva et al. 2013). The flavanone pinocembrin (Fig. 1C), probably derived from Populus species, has been detected in brown propolis (Koo et al. 1999; Adelmann et al. 2007). HPLC analysis of the ethanol extract of a propolis from the state of Santa Catarina suggests that it derives from Populus alba (Park et al. 2002). Diterpenes from Araucaria angustifolia (Brazilian native conifer), such as sugiol (Fig. 11C) and agathic acid (Fig. 11D), have been detected in brown propolis (Bankova et al. 1996). Other diterpenes from undetermined origin have also been reported for this propolis type (Tazawa et al. 2016). The essential oil obtained from a propolis from the state of Paraná (southern Brazil) contains almost exclusively $\alpha$ - and $\beta$-pinenes, suggesting derivation from locally cultivated Pinus species (Mayworm et al. 2017). Present available evidence indicates that brown propolis is chemically diverse, gaining contribution of resins from either native or cultivated plant species.

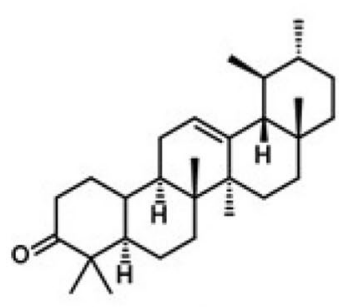

A. Amyrinone

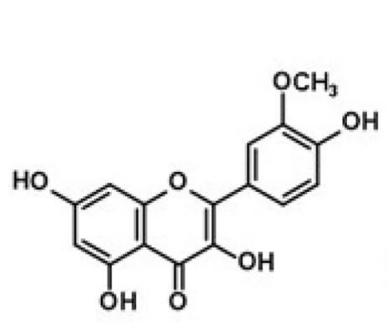

B. Isorhamnetin

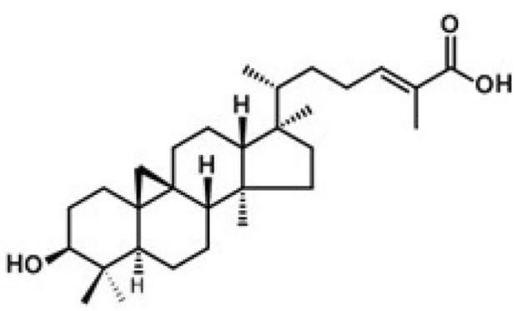

C. Mangiferolic acid

Figure 9. Constituents of a dark propolis produced in the state of Piauí (northeast Brazil). 


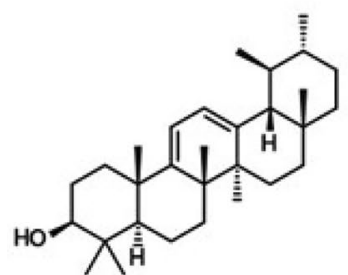

A. Ursa-9(11),12-dien-3-ol

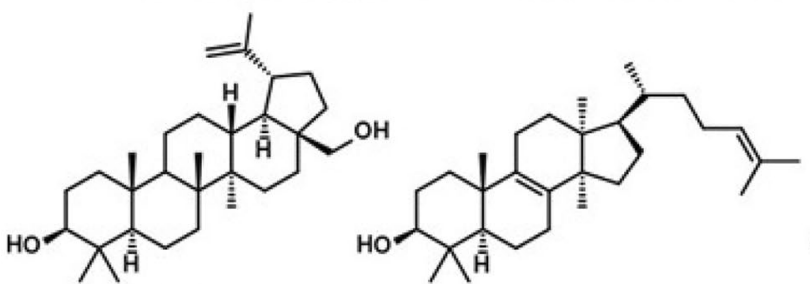

D. Betulin

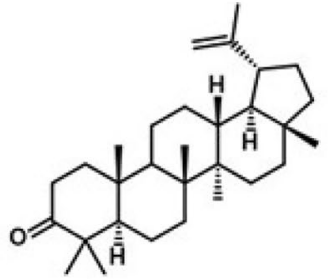

B. Lup-20(29)-en-3-one

E. Lanosterol<smiles>CC1(C)CCC2(C)C(=CCC3[C@@]4(C)CCC(=O)C(C)(C)[C@@H]4CC[C@]32C)C1</smiles>

C. Olean-12-en-3-one

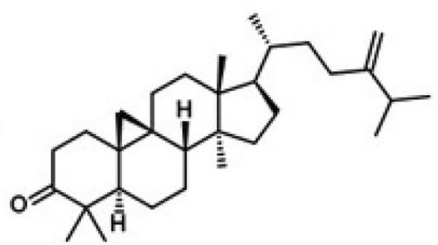

F. Methylenecycloarten-3-one

Figure 10. Triterpenoids and steroids of yellow propolis from the Pantanal biome, in the state of Mato Grosso do Sul (West-Central Brazil).

\subsubsection{Within-type variation of Brazilian propolis}

Propolis chemical composition varies widely, depending mainly on seasonality, locality, and vegetation (Bankova 2005; Valencia et al. 2012). Propolis composition varies not only from one type to another but among samples of a same type. For example, differences have been observed comparing the composition of red propolis from Cuba and Brazil (GiménezCassina et al. 2014). Dalbergia ecastaphyllum is recognized as the plant source of resin for both Brazilian and Cuban red propolis. However, only Brazilian red propolis has been reported to possess a second plant source, probably a Clusia species, from which derive prenylated benzophenones, namely, guttiferone $\mathrm{E}$, xanthochymol, and oblongifolin A (Piccinelli et al. 2011). The effect of seasonality on Brazilian propolis composition has been extensively studied (Bankova et al. 1998; Jorge et al. 2008; Teixeira et al. 2010; Souza et al. 2016; Bueno-Silva et al. 2017; Regueira Neto et al. 2017). Seasonal quantitative chemical differences have been reported also for Brazilian red propolis (Bueno-Silva et al. 2017).

Several factors may account for seasonal variations of propolis. The composition of essential oils is susceptible to seasonal factors (Hussain et al. 2010). The availability of plants or plant parts providing resin varies according to the season of the year, particularly in annual or biennial<smiles>COc1cc(O)cc2oc(-c3ccc(O)c(O)c3)cc(=O)c12</smiles>

A. Luteolin-5-0-methyl ether<smiles>CC(C)c1cc2c(cc1O)C1(C)CCCC(C)(C)[C@H]1CC2=O</smiles>

B. Sugiol<smiles>C=C1CCC2(O)[C@@H](CCCC2(C)C)C1CCC(C)=CC(=O)O</smiles>

C.Agathic acid

Figure 11. A flavonoid and diterpenes of brown propolis from regions of Araucaria (Araucariaceae) forests, in the south of Brazil. 
species. Honey bees depend on the availability of young tissues of B. dracunculifolia for propolis production (Teixeira et al. 2005). During the plant reproductive period (December-May), little or no vegetative young tissues are available (Bastos et al. 2011). Regarding species of Clusia, the opposite is the case, because the resin they provide and used by bees for propolis production are exudates from female flowers (Tomás-Barberán et al. 1993; Cuesta-Rubio et al. 2002).

Substantial differences have been noticed comparing propolis from $B$. dracunculifolia, comparing one locality of production with another. The typical Brazilian green propolis is produced in the central part of the state of Minas Gerais, corresponding to the dispersion geographic core of $B$. dracunculifolia. The propolis from this region is vivid green, stiff, and friable. Only products with these characteristics have commercial value. In that region, contribution of resin from other species is meager or null. However, in certain regions or during some periods, the availability of individuals of $B$. dracunculifolia reduces. Under these circumstances, the contribution of resin from alternative plant sources increases. The higher the contribution of $B$. dracunculifolia plants, the stiffer is the propolis produced and more vivid its greenness. The reverse picture is a sticky, moldable, and dark propolis. Constituents derived from B. dracunculifolia may be detected in these propolis samples, but their concentration is lower than in the commercially valuable stiff and dark green propolis. Typical samples of $B$. dracunculifolia propolis contain high quantity of phenolic constituents and low amount of wax, being usually triterpenoid-free. In contrast, dark propolis samples, albeit bearing typical chemical markers of $B$. dracunculifolia (artepillin $\mathrm{C}$ and prenyl-3-cinnamic acid allyl ester; Fig. 3A and B, respectively), have low content of phenolic substances and high contents of wax and triterpenoids, such as $\beta$-amyrin and its acetate (Fig. 12A and B), lupeol (Fig. 12C) (Negri et al. 2000), or bauerenyl acetate (Fig. 12D) (Negri et al. 2003b; Teixeira et al. 2006), among other lipophilic constituents. It seems clear that triterpenoids in Brazilian green propolis derive from sources other than B. dracunculifolia. Analysis by microscopy of a deep dark propolis, with moldable texture, produced in the municipality of Virginópolis (state of Minas Gerais, southeast Brazil), revealed fragments of young leaves of both $B$. dracunculifolia and Vernonia rubriramea (Asteraceae) (Freire 2000). Propolis with such characteristics have low or no commercial value.

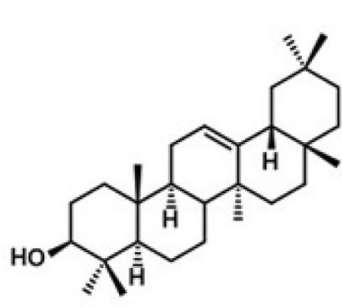

A. $\beta$-Amyrin

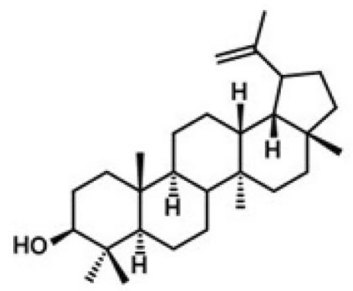

C. Lupeol

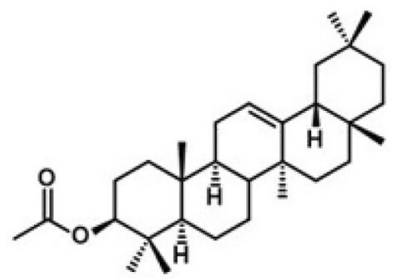

B. $\beta$-Amyrin acetate

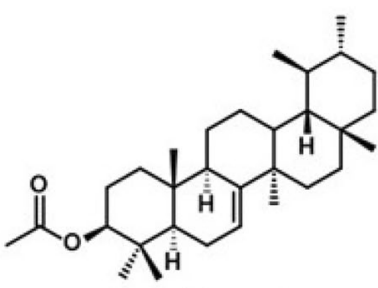

D. Bauer-7-en-3 $\beta$-y acetate

Figure 12. Triterpenoids from propolis dark propolis containing also phenolic compounds derived from Baccharis dracunculifolia (Asteraceae). 
Contrasting physical and chemical characteristics among propolis samples derived from $B$. dracunculifolia are not exclusive of Brazil. Nina et al. (2016) reported the composition of several propolis samples from Bolivia. All samples analyzed contain artepillin $\mathrm{C}$ and other constituents of $B$. dracunculifolia, although propolis from distinct localities are physically and chemically different: propolis from Bolivian valleys are green and stiff and have high contents of prenylated phenylpropanoids and antioxidant activity; in contrast, propolis samples from La Paz and Santa Cruz are dark and moldable, with high predominance of cycloartane and pentacyclic triterpenoids and weak antioxidant activity. The results by Nina et al. (2016) reveal that $B$. dracunculifolia is source not only of Brazilian but also of Bolivian propolis. Since no cycloartane triterpenoids have been detected in Brazilian green propolis, the sources of triterpenoids are distinct in one and another country for this type of propolis.
Figure 13 is a hypothetical representation of the balance phenolics/triterpenoids, based on results of papers about $B$. dracunculifolia propolis (Negri et al. 2000, 2003a, 2003b; Teixeira et al. 2005, 2010; Nina et al. 2016). On the right end of the graph lies the typical green propolis from Minas Gerais, rich in phenolic substances and virtually devoid of triterpenoids. On the other extreme lies dark propolis with high contents of triterpenoids and low quantity of phenolic substances. It is hypothesized that the gradient between the two extremes is determined by the relative abundance of $B$. dracunculifolia plants and their contribution to propolis resin: the higher the availability, the higher the proportion of prenylated phenylpropanoids and the lower the proportion of wax and triterpenoids and vice versa. The intensity of the antioxidant activity follows the same trend: the higher the contribution of B. dracunculifolia, the higher the activity.

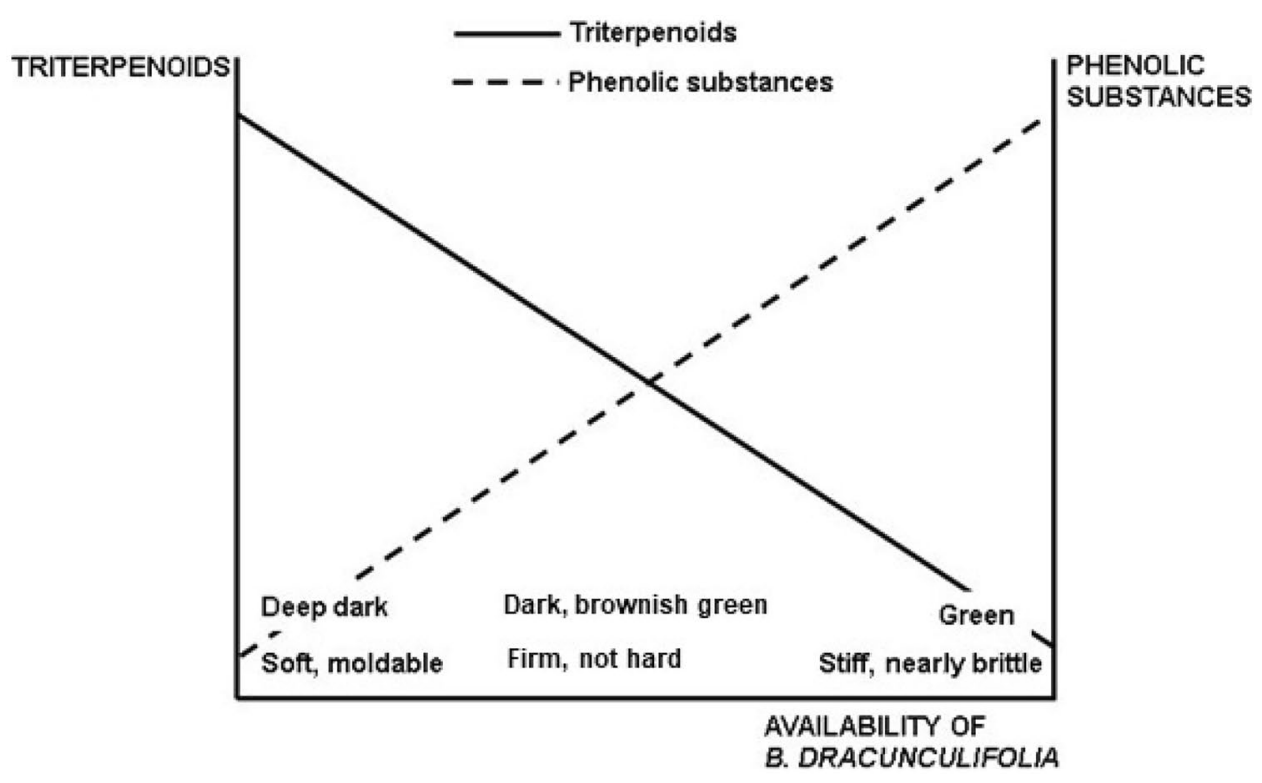

Figure 13. Hypothetical relationships between the relative contents of phenolic substances and triterpenoids in green propolis as dependent on the availability of individuals of Baccharis dracunculifolia (Asteraceae) in the site of propolis production. On the bottom of the graphic are described physical characteristics of the propolis, also dependent on the availability of $B$. dracunculifolia. 


\section{SPECTRUM WIDTH OF BOTANICAL SOURCES: CONSTRAINTS}

Honey bees are pollinators of a wide diversity of angiosperms. They seek pollen and nectar from congested inflorescences or flowers with short corolla tube, containing abundant pollen and nectar. Flowers or inflorescences of honey bee pollinated plants attract bees by their odor and bright yellow or blue coloration, often with ultraviolet absorbing nectar guides (Fenster et al. 2004). Most relationships between plants and bee pollinators are a coevolutionary and bilateral gaining process. Thus, it is a mutualistic interaction that has been fostered over the evolution of plants and insects. The characteristics associated with pollination of flowers and bees are the result of a process of coevolution that started early in the diversification of the eudicotyledons, on one side, and the Apidae, on the other (Cappellari et al. 2013). Over time, the number of bee pollinated plants increased, as well as the number of pollinator bee species. The web site Worldatlas (2018) lists 95 crop species dependent on honey bees for pollination. The total number of honey bee-pollinated wild species is unknown, but certainly it is astounding.

On the other hand, collection of resins by bee foragers is a unilateral gaining process of commensalism or parasitism, from which only the insects get advantage. There have been no attempts to determine when bees started collecting plant resins and producing propolis. Probably, this is a recent evolutionary (but not coevolutionary) process, which has evolved not in all honey bee species (Simone-Finstrom and Spivak 2010). Most likely, the number of angiosperm species foraged by honey bees for collection of propolis resin is much lower than the number of species they visit for pollen and nectar collection. Contrary to pollination, mechanisms to attract bee resin foragers have never been selected over the evolution of plant species. From the plant side, no advantage is apparent from production and provision of resin to propolis producers. On the contrary, resin collection from young vegetative tissues is somewhat similar with defoliations caused by leaf-cutter ants, although the loss of green tissues due to honey bee foragers is much lower. However, an exceptional case of mutualism between plant resin sources and honey bees has been pointed out, involving a co-evolution between stingless bees and Clusia grandiflora in South America: the floral resins play the role of nonnutritive pollinator reward for the native bees, which use them as nest construction material with effective antibacterial properties (Lokvam and Braddock 1999).

On the honey bees turn, resin collection is a difficult and time-consuming process. The proportion of total honey bee laborers collecting resins is less than $1 \%$ of the total forager work force (Borba et al. 2017). Several kinds of constraints may be pointed out as factors that magnify the burden represented by resin collection by bee laborers and narrow the diversity of plant species candidate as sources of resin for honey bee propolis.

\subsection{Functional constraints}

Paraphrasing Fraenkel (1959), the "raison d'être" for the investment of labor and energy toward the collection of plant resins is the benefits brought about by propolis as a barrier against enemies of the hive. The resin to be collected must be loaded with substances possessing antimicrobial activity (Simone-Finstrom and Spivak 2010; Wilson et al. 2013). It is no surprise that, despite differences in geographic locality and chemical composition, most propolis types investigated so far have been shown to exert activity against a wide diversity of microorganisms (de Groot 2013), including bacteria (Przybylek and Karpinski 2019), viruses (Fischer et al. 2007), and fungi (Oliveira et al. 2006). Also, propolis has revealed activity against honey bee parasites, such as the gut infecting microsporidium Nosema ceranae (Mura et al. 2020) and the mite Varroa infestans (Pusceddu et al. 2018). The use of plant resins by honey bees has been characterized as a self-medication process, by which propolis substances, on one side, exert detrimental effects on parasites and, on the other side, 
increase bee fitness and the social immunity of the hive (Simone-Finstrom et al. 2012; Borba et al. 2017; Pusceddu et al. 2018).

Factors guiding honey bees to plant sources containing biologically active resins are still largely speculative. Tropical stingless bees locate tree sources of resin using terpenes as olfactory cues (Leonhardt et al. 2010). Several types of propolis (e.g., B. dracunculifolia and poplar propolis) have mono- and sesquiterpenes and other volatile compounds in their composition (Bankova et al. 2014). Tactile stimuli have been suggested as a possible mechanism in the behavior of honey bee resin foragers (SimmoneFinstrom et al. 2010).

Most plant species are loaded with biologically active secondary metabolites. These substances have been selected over time for providing chemical defense against pathogens and herbivores (Neilson et al. 2013). Various plant species secrete highly antimicrobial resins that protect vegetative apices and young leaves, wounded tissues, etc. (Shuaib et al. 2013). Substances acting as barriers against the attack of plant enemies may be useful also as chemical defense of bees against their enemies. However, only a minority among plant species possessing these substances may be suitable sources of propolis resins to be foraged by honey bees. Next sections discuss other constraints limiting the number of plant sources of propolis resin.

\subsection{Physical-mechanical constraints}

Exudates on plant surfaces may turn out propolis resins that are accessed by honey bee foragers. Examples are poplar propolis, Brazilian red propolis, and Okinawan propolis (Kumazawa et al. 2008). But not all surface exudates are amenable to be collected by honey bees. Many plants have glandular hairs that release viscous-adhesive fluids, capable of entrapping and intoxicating insects and other arthropods (Jiménez-Pomárico et al. 2019). Other plants release exudates, such as gums, that are too sticky to be handled by the mouthparts of honey bee foragers. Other plant secretions have liquid or viscous texture when released but harden over time, as is the case of frankincense. So far, no propolis with resin derived from latices has been reported. Thus, a limited range of plant exudates fit conditions of being manipulated by bee foragers and then used as propolis resin.

Several secretions become available on the plant surface only occasionally. Examples are exudates that are released as a reaction to injuries caused by insect borers. In other cases, plant secretions become available during logging. The latter seems to be the case of resins of Araucaria angustifolia in south Brazil. Although diterpenes of this species have been detected in brown propolis (Bankova et al. 1996), several other papers did not detect Araucaria constituents in propolis from south Brazil. Thus, it seems that, unlike B. dracunculifolia, Araucaria is not a regular provider of resins of Brazilian propolis. A similar situation holds for Pinus trees. Logging of several cultivate north American species of Pinus is frequent in Brazil. A brown propolis from Paraná state yielded $13 \%$ of volatile oils containing mostly $\alpha$ - and $\beta$-pinenes, main components of pine turpentine oil (Mayworm et al. 2017). The resin of D. ecastaphyllum is a pathological secretion, being released upon injuries inflicted on the stems by borer insects. To stimulate resin release, apiculturists in northeast Brazil promote mechanical injuries to the stems, with results similar with natural injuries caused by borer insects. Only in this way D. ecastaphyllum turns out a regular provider of red propolis resin.

Alternatives to surface exudates for honey bee foragers are young tissues of plant apices. In Brazil, honey bees cut and chew fragments of young vegetative tissues of few plant species, such as $B$. dracunculifolia from the Cerrado and Mimosa tenuiflora from the Caatinga. Young vegetative tissues of both species are thin, almost devoid of fibers and other mechanical elements. They are also free of silica bodies on their surfaces.

Probably, many species from Cerrado and other Brazilian biomes could be sources of 
propolis resin, were it not for the thickness and/ or hard texture of their tissues. Likely physical factors constraining bees to cut and chew plant tissues are histological components of plant tissues, such as thick cell walls and mechanical elements (fibers and sclereids). Mechanical anti-herbivore defenses play an important role in Cerrado species, as part of the syndrome of oligotrophic scleromorphism (Salatino 1993; Ribeiro et al. 1999). Often, leaves of Cerrado plants are thick, leathery, and tough, hence the designation "schlerophyllous" to them. Sclerophyllous leaves often have rigid trichomes and mechanical elements, in addition to oxalate and silicate crystals in the mesophyll. In leaves of several Cerrado species, such as Curatella americana and Davilla elliptica, siliceous phytoliths are abundant, represented by crystalline deposits within the epidermal cells and on their rigid trichomes (Lepsch et al. 2014). Phytoliths on the leaf surfaces account for the rough sandpapery feeling at the touch. Probably, the sclerophylly of many Cerrado plant species represents an unbreakable barrier to the cutting possibilities of the mandibles of forager honey bees. Actually, honey bees seem to be unable to cut even adult leaves of $B$. dracunculifolia, which are far from being sclerophyllous. Comparing their leafcutting capacity, the mandibles of the lappingchewing mouthparts type of honey bees with the mandibles of the chewing type mouthparts of leaf-cutter ants, the former is at a far distant disadvantage relative the latter. Leaf-cutter ants are generalists, cutting fresh leaves of a wide diversity of monocotyledons and eudicotyledons. Honey bee mandibles look small and fragile in comparison with the comparatively massive mandibles of leaf-cutter ants (Fig. 14). This means that the capacity of both insects to cut and chew plant tissues is highly distinct. If honey bee mandibles were larger and their associated muscles stronger, the number of plant species exploited as sources of plant resin could be considerably higher (Salatino and Salatino 2017). Leaf sclerophylly helps understand why, among Cerrado plant species, so far only young tissues of $B$. dracunculifolia has been reported to be a regular botanical source of Brazilian propolis resin. The Caatinga legume species $M$. tenuiflora is another species with tender young vegetative tissues, which thus are amenable to the cut and chewing actions of the honey bees mouthparts (Ferreira et al. 2017). Coincidentally, B. dracunculifolia and M. tenuiflora propolis are so far the only known Brazilian propolis types with green color, which is accounted for their contents of chlorophylls derived from the aerial apical tissues of the plants.

In this regard, the finding by Duke et al. (2017) about a brown propolis from Kangaroo

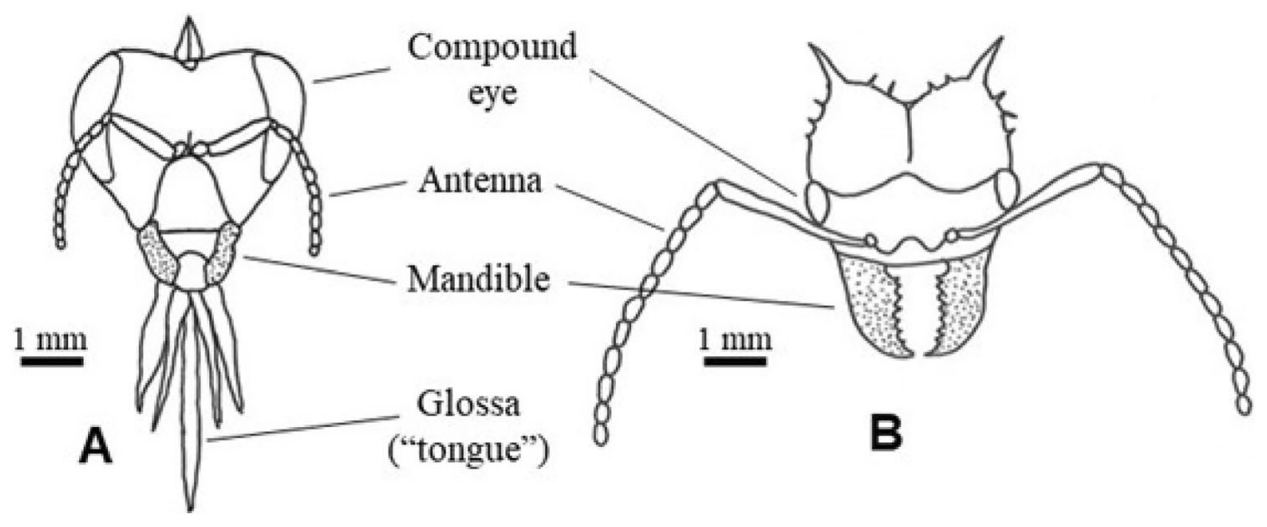

Figure 14. Simplified representation of mouth parts of insects. (A) Chewing-lapping type (Apis mellifera); based on https://pt.slideshare.net/ARUN5218/mouth-parts-of-insect-and-types (accessed August 20 2020). (B) Chewing type (leaf-cutter ant; Atta sp.); based on https://askabiologist.asu.edu/sites/default/files/resources/coloring_pages/pdf/aab_ ant_head_matching_activity.pdf (accessed August 20, 2020). 
Island (Australia) is enlightening. The resin is derived from a sedge (species of the Cyperaceae family) belonging to the genus Lepidosperma. Sedges are similar with grasses, in the sense that they possess leaves physically protected by sheaths of schlerenchymatic fibers. Duke et al. (2017) observed that honey bees collect resin droplets that are exuded to the leaf margins. This is the first report of propolis derived from Cyperaceae and, to our knowledge, the first report of propolis resin provided by a monocotyledon species. Monocotyledon large families, such as Poaceae (grasses), Cyperaceae (sedges), and Arecaceae (palm trees), have leaves with bundle sheaths comprising layers of schlerenchimatic fibers and silica bodies (Prychid et al. 2003). In the same Australian island is produced a different propolis, with high contents of methoxylated flavonoids (chalcones, flavonols, and dihydroflavonols), derived from exudates of pods of Acacia paradoxa (Tran et al. 2012).

\subsection{Chemical-toxicological constraints}

Detrimental effects on insects by plant secondary metabolites (Kortbeek et al. 2018; War et al. 2018) are likely another major constraint, narrowing the spectrum of potential sources of antimicrobial propolis resin. Secondary metabolites (also designated as specialized metabolites) have long been known to be insecticides or harmful to insects. Secondary metabolites containing nitrogen stand out as plant anti-herbivore defenses. Nicotine, an alkaloid, has been used as insecticide since 1690 (Tomizawa and Casida 2005). Glucosinolates are common and effective anti-herbivore defenses of Brassicaceae, such as cabbage and mustards (Tsao et al. 2002). Cyanogenic glycosides, detected so far in more than 2600 plant species, are toxic to arthropods (Zagrobelny et al. 2018). Hydrocyanide (HCN), a volatile compound released upon hydrolysis of cyanogenic glycosides, is toxic to aerobic organisms (van Ohlen et al. 2016). To the best of our knowledge, so far nitrogenous secondary metabolites have not been reported as constituents of honey bee propolis, although pyrrolizidine alkaloids have been detected as constituents of propolis from a stingless bee species (Coelho et al. 2015). Monocrotaline, a Crotalaria widespread pyrrolizidine alkaloid, is deterrent and toxic to honey bees (Reinhard et al. 2009). The isothiocyanates derived from hydrolysis of glucosinolates are deterrent and toxic to insects (Hopkins 2009).

Studying effects on honey bees, Detzel and Wink (1993) evaluated the attractive, deterrent, and toxic activities of substances belonging to distinct classes of secondary metabolites. Regarding nitrogenous substances, out of 22 alkaloids, 21 were deterrent, and among them, 15 were toxic; allyl isothiocyanate, a product of hydrolysis of the glucosinolate sinigrin, and amygdalin, a cyanogenic glycoside from Prunus species, were deterrent and toxic. Not only nitrogenous, but other classes of secondary metabolites were deterrent and toxic to honey bees in the mentioned experiment. The volatile oils of Lavandula, Melissa, Rosmarinus, Syzygium, and Thymus were deterrent and toxic; the volatile oil of Citrus was attractive, but nonetheless toxic. Coumarins are phenolic compounds, several of them toxic to vertebrates and insects (Sarker and Nahar 2017). Three coumarins-coumarin itself, aesculin, and umbelliferone-were shown to be deterrent and toxic to honey bees; in addition, a saponin and a sample of tannin were also deterrent and toxic (Detzel and Wink 1993).

Saponins are glycosides with a triterpenoid or steroidal nucleus, having deterrent and toxic effects on insects (De Geyter et al. 2007; Chaieb 2010). Tannins are phenolic polymers that bind strongly with proteins and may be toxic due to oxidative stress they cause on herbivores (Salminen and Karonen 2011; Barbehenn and Constabel 2011). Saponins and tannins are widespread in vascular plants, and thus several propolis types probably contain at least detectable amounts of these secondary metabolites (Mayworm et al. 2014). High tannin content is common in plant species of Cerrado and is associated with sclerophylly (Madeira et al. 1998), while saponins are abundant in many species of Cerrado and other biomes. 
The results of Detzel and Wink (1993) are relevant to reveal the amplitude of classes of secondary metabolites that may be detrimental to honey bees. Out of 39 allelochemicals tested, most exhibited deterrent effect, among which 17 exerted some degree of toxicity. It is interesting to notice that, among the classes of metabolites tested, flavonoids were almost devoid of negative effects. Among six flavonoids tested, only catechin (a monomer constituent of condensed tannins) had deterrent and toxic effect. All other flavonoids showed no effect in the feeding tests. This observation is coherent with their utility by honey bees, derived from their known antimicrobial and immune stimulating effect, with no collateral toxic effects. Detzel and Wink (1993) tested the effects of substances dissolved in nectar, a substance that is engorged by worker bees and treated by enzymes in the crop or honey stomach (Sammataro and Cicero 2010). The resin is not ingested by foraging bees, so that the two foraging processes (nectar and resin collection) cannot be placed side by side regarding toxicity. On the other hand, they are comparable regarding deterrence, so that resins containing unpalatable and potentially toxic substances, such as bitter alkaloids and saponins, as well as astringent tannins, are likely avoided by foraging workers.

The above comments about the non-toxicity of resins collected and manipulated by honey bees is an argument in line with the common claim that propolis is safe for human consumption. Propolis is assumed as a non-toxic product, in part due to experiments of toxicological effects of flavonoids, carried out with mice. It was noted that the toxicity of flavonoids to mice is extremely low, values of $\mathrm{LD}_{50}$ ranging from 8000 to $40,000 \mathrm{mg} / \mathrm{kg}$ (Havsteen 1983).

\subsection{Brazilian biomes: plant megadiversity vs. narrow diversity of propolis plant sources}

Brazil is a country with continental expanse, biome diversity (Fig. 2), and a recognized plant megadiversity (Canhos et al. 2015). One of the first themes we learn at school about plant-animal relationships is pollination and the wide diversity of bee-visited flowers. At a first evaluation, one is led to imagine that a similar picture should hold regarding the interaction between bees and plant sources of resins. Therefore, it is normally expected to exist a wide diversity of plant sources of Brazilian propolis. In fact, this assumption is implicit on comments of authors in many papers of propolis literature. The opposite picture, i.e., the idea that only a narrow diversity of Brazilian plant species is suitable as resin sources for propolis production, is counterintuitive. Contrary to the logical reasoning based on taxonomic megadiversity and plant chemical plurality (Sen and Samanta 2015), results of the first estimation of the number of propolis types in Brazil came out with only 12 types, upon examination of nearly 500 samples of propolis, covering a wide expanse of the Brazilian territory (Park et al. 2000). Not many types of Brazilian propolis and corresponding plant sources have been later characterized, such as the mangrove red, the Amazonian black, and the Caatinga green types (Table 1, Fig. 2). Given all the requisites that a plant must fulfil to be become resin providers of propolis, it comes not as a surprise the low number of species that are effective plant origins of Brazilian propolis.

Much is still necessary to get a wider and more realistic magnitude of the diversity of Brazilian propolis types. New chemically distinct types are expected to be characterized, along with corresponding plant origins. Honey bees have high adaptive capacity and are efficient explorers of environmental resources. For example, if challenged to grow in the absence of their preferred plant source of propolis resin (B. dracunculifolia) resin, honey bee hives managed to find new sources (Piperaceae plants; Fernandes-Silva et al. 2020). With time, undoubtedly the list of plant sources on Table 1 will be considerably expanded. The prospect, however, is that the list will stand within a limited range, far below the diversity of honey bee pollinated plant species. 


\section{CONCLUSION}

Brazilian plant megadiversity and its potentiality to provide natural resources have become a cliché in both scientific and common literature. It is normally assumed that many plant species in Brazilian flora are effective or potential providers of propolis resin types and that it is just a matter of time until many new plant resources of resin and propolis types are uncovered. However, over 20 years of Brazilian propolis research have gone by and the number of plant species experimentally pointed out as providers of resin for propolis production in Brazil remains limited to less than ten species. Physical-mechanical, functional, and chemical-toxicological factors have conspired to restrain the number of plant sources of propolis resin within a limited range. This comment holds not only for Brazilian propolis but for propolis from other parts of the world as well. Evidently, much remains to be done and probably substantial increments of the number of plant origins and propolis types are expected. However, comparing with the diversity of bee-pollinated plant species, the prospects are not favorable toward a revolutionary widening of the present known diversity of plant sources of honey bee Brazilian propolis.

\section{AUTHOR CONTRIBUTION}

AS prepared the first draft of the manuscript; MLFS and GN contributed with comments and opinions; all authors read and approved the final version of the paper.

\section{FUNDING}

The authors thank funds provided by FAPESP (Fundação de Amparo à Pesquisa do Estado de São Paulo, grants 2011/06423-5 and 2013/21813-0). AS is senior fellow researcher of CNPq (Conselho Nacional do Desenvolvimento Científico e Tecnológico, Brazil).

\section{DATA AVAILABILITY}

The present paper is a review article, and no datasets were generated or analyzed during the study. Hence, this item is not applicable.

\section{DECLARATIONS}

Ethical approval Not applicable.

Competing interests The authors declare no competing interests.

\section{REFERENCES}

Adelmann J, Passos M, Breyer DH, Rocha dos Santos MH, Lenz C, Leite NF, Lancas FM, Fontans JD (2007) Exotic flora dependence of an unusual Brazilian propolis: the pinocembrin biomarker by capillary techniques. J Pharmeut Biomed 43:174-178.

Aguero MB, Svetaz L, Sanchez M, Luna L, Lima B, Lopez ML, Zacchino S, Palermo J, Wunderlin D, Feresin GE, Tapia A (2011) Argentinian Andean propolis associated with the medicinal plant Larrea nítida Cav. (Zygophyllaceae). HPLC-MS and GC-MS characterization and antifungal activity. Food Chem Toxicol 49:1970-1980.

Aldana-Mejia JA, Ccana-Ccapatinta GV, Ribeiro VP, Arruda C, Veneziani RCS, Ambrosio SR, Bastos JK (2021) A validated HPLC-UV method for the analysis of phenolic compounds in Brazilian red propolis and Dalbergia ecastaphyllum. J Pharm Biomed Anal 198 (https://doi.org/10.1016/j.jpba. 2021.114029)

Alves RJV, Silva NG, Oliveira JA, Medeiros D (2014) Circumbscribing campo rupestre - megadiverse Brazilian rocky montane savannas. Braz J Biol 74:355-362.

Anjum SI, Ullah A, Khan KA, Attalullah M, Himatullah HA, Bashir MA, Tahir M, Ansari MJ, Ghramh HA, Adgaba H, Dash CK (2019) Composition and functional properties of propolis (bee glue): a review. Saudi J Biol Sci 26:1625-1703.

Arieira J, Karssenberg D, de Jong SM, Addink EA, Couto EG, da Cunha N, Skoien JO (2011) Integrating field sampling, geostatistics and remote sensing to map wetland vegetation in the Pantanal, Brazil. Biogeosciences 8:667-686.

Awale S, Prakash S, Tezuka Y, Ueda J, Matsushige K, Kadota S (2005) Neoflavonoids and related constituents from Nepalese propolis and their nitric oxide production inhibitory activity. J. Nat. Prod 68:858-864.

Bankova V, Boudourova-Krasteva G, Popov S, Sforcin JM, Funari SRC (1998) Seasonal variations of the chemical composition of Brazilian propolis. Apidologie 29:361-367. 
Bankova V. (2005) Recent trends and important developments in propolis research. Evid-Based Compl Alt 2:29-32.

Bankova V, Marcucci MC, Simona S, Nikolova N, Kujumgiev A, Popov S (1996) Antibacterial diterpenic acids from Brazilian propolis. Z Naturfors C 51:277-280.

Bankova V, Popova M (2007) Propolis of stingless bees: a promising source of biologically active compounds. Pharmacogn Rev 1:88-92.

Bankova V, Popova M, Trusheva B (2006) Plant sources of propolis: an update from a chemist's point of view. Nat Prod Commun 1:1023-1028.

Bankova V, Popova M, Trusheva B (2014) Propolis volatile compounds: chemical diversity and biological activity: a review Chem. Cent. J. 8 (https://doi.org/ 10.1186/1753-153X-8-28)

Banzato TP, Gubiani JR, Bernardi DI, Nogueira CR, Monteiro AF, Juliano FF, de Alencar SMA, Pilli RA, de Lima CA, Longato GB, Ferreira AG, Foglio A, de Carvalho JE, Vendramini-Costa DB, Berlinck RGS (2020) Antiproliferative flavanoid dimers isolated from Brazilian red propolis. J Nat Prod 83:1784-1793.

Barbehenn RV, Constabel CP (2011) Tannins in plantherbivore interactions. Phytochemistry 72:1551-1565.

Bastos EMAF., Santana RA, Calaça-Costa AGF, Thiago PS (2011) Interaction between Apis mellifera L. and Baccharis dracunculifolia DC that favors green propolis production in Minas Gerais. Braz J Biol 71:727-734.

Bees for Development (2016) Factsheet: propolis. http:// www.beesfordevelopment.org/media/1448/factsheetpropolis-web-email-jun-2016.pdf; Accessed August 202020.

Bertrams J, Muller MB, Kunz N, Kammerer DR, Stintzing FC (2013) Phenolic compounds as marker compounds for botanical origin determination of German propolis samples on TLC and TLC-MS. J Appl Bot Food Qual 86:143-153.

Beserra FP, Gushiken LFS, Hussni MF, Ribeiro VP, Bonamin F, Christopher JJ, Pellizzon CH, Bastos JK (2020) Artepillin C as an outstanding phenolic compound of Brazilian green propolis for disease treatment: a review on pharmacological aspects. Phytoth Res 35:2274-2286.

Borba RS, Wilson MB, Spivak M (2017) Hidden benefits of honeybee propolis in hives. In: Vreeland $\mathrm{RH}$ and Sammataro D (eds) Beekeeping - From Science to Practice. Springer, Belle Haven, pp 17-38.

Bueno-Silva B, Marsola A, Ikegaki M, Alencar SM, Rosalen PL (2017) The effect of seasons on Brazilian red propolis and its botanical source: chemical composition and bacterial activity. Nat. Prod Res 31:1318-1324.

DAL Canhos MS Sousa-Baena S Souza LC Maia JR Stehman VP Canhos R Giovanni De MBM Bonacelli L Walter T Peterson 2015 The importance of biodiversity E-infrastructures for megadiverse countries PLoS Biology 2015 (https:// doi.org/10.1371/journal.pbio.1002204)

SC Cappellari H Schaefer CC Davis 2013 Evolution: pollen or pollinators - which came first? Current Biology 23 (https://doi.org/10.1016/j.cub.2013.02.049)

Ccana-Ccapatina G, Mejía JA, Tanimoto MH, Groppo M, de Carvalho JCAS, Bastos JK (2020) Dalbergia ecastaphyllum (L.) Taub. And Symphonia globulifera L.f.: the botanical sources of isoflavonoids and benzophenones in Brazilian red propolis. Molcules 25 ( https://doi.org/10.3390/molecules25092060)

Chaieb I (2010) Saponins as insecticides: a review. Tunis J Plant Prot 5:39-50.

GR Coelho RZ Mendonça KD Vilar CA Figueiredo JC Badari N Taniwaki G Namiyama MI Oliveira de SP Curti PE Silva G Negri 2015 Antiviral action of hydromethanolic extrac of geopropolis from Scaptotrigona postica against antiherpes simplex virus (HSV-1) Evid-Based Compl Alt 2015 (https://doi. org/10.1155/2015/296086)

Cuesta-Rubio O, Frontana-Uribe BA, Ramirez-Apan T, Cardenas J (2002) Polyisoprenylated benzophenones in Cuban propolis; biological activity of nemorosone. Z Naturf C 57:372-378.

Fenster CB, Armbruster WS, Wilson P, Dudash MR, Thomson JD (2004) Pollination syndromes and floral specialization. Annu Rev Ecol Evol 35:375-403.

Daugsch A, Moraes DS, Fort P, Park YK. 2008. Brazilian red propolis - chemical composition and botanical origin. Evid-Based Compl Alt 5:435-441.

da Silva MDS, Cito AMCL, Chaves MH, Lopes JAD (2005) Cycloartane triterpenoids of propolis from Teresina. Quim Nova 28:801-804.

de Albuquerque IL, Alves LA, Lemos TLG, Monte FJQ, Braz Filho R (2007) Canaric acid (3,4-seco-lupane derivative) isolated from propolis of Ceará. Quim Nova 30:828-831.

De Geyter E, Lambert E, Geelen D, Smagghe G (2007) Novel advances with plant saponins as natural insecticides to control pest insects. Pest Tech 1:96-105.

de Groot AC (2013) Propolis: a review of properties, applications, chemical composition, contact allergy, and other adverse effects. Dermatitis 24:263-282.

Detzel A, Wink M (1993) Attraction, deterrence or intoxication of bees (Apis mellifera) by plant allelochemicals. Chemoecology 4:8-18.

dos Santos DC, David JM, David JP (2017) Chemical composition, cytotoxic activity and antioxidant of a propolis type from Bahia. Quim Nova 40:171-175.

Duke CC, Tran VH, Duke R, Abu-Mellal A, Plunkett GT, King DI, Hamid K, Wilson KL, Barrett RL, Bruhl JJ (2017) A sedge plant as the source of Kangaroo Island propolis rich in prenylated $p$-coumarate ester and stilbenes. Phytochemistry 134:87-97.

Dumig A, Schad P, Rumpel C, Dignac MF, Kogel-Knabner I (2008) Araucaria forest expansion on grassland in the southern Brazilian highlands as revealed by C-14 and delta C-13 studies. Geoderma 145:143-157. 
Fernandes-Silva CC, Salatino A, Motta LB, Negri G, Salatino MLF (2019) Chemical characterization, antioxidant and anti-HIV activities of a Brazilian propolis from Ceará state. Rev Bras Farmacog 29:309-318.

Fernandes-Silva CC, Salatino A, Salatino MLF (2013) Chemical profiling of six samples of Brazilian propolis. Quim Nova 36: 237-240.

Fernandes-Silva CC, Teixeira EW, Alves MLTMF, Negri G, Salatino MLF, Salatino A (2020) Propolis obtained in a clearing inside the Atlantic Forest in Ubatuba (São Paulo state, Brazil): essential oil and possible botanical origin. J Apicult Res 2020 (https://doi.org/10.1080/00218839.2020.1797994)

Ferreira JM, Fernandes-Silva CC, Salatino A, Negri G, Message D (2017) New propolis type from north-east Brazil: chemical composition, antioxidant activity and botanical origin. J Sci Food Agr 97:3552-3558.

Fischer G, Cleff MB, Dummer LA, Paulino N, Paulino AS, Vilela CO, Campos FS, Vargas GDA, Hübner SO, Vidor T (2007) Adjuvant effect of green propolis on humoral immune response of cattle immunized with bovine herpesvirus type 5. Vet Immunol Immunopathol 116:79-84.

Fraenkel GS (1959) The raison d'être of secondary plant substances. Science 129:1466-1470.

Franceschinelli EF, Jacobi CM, Drummond MG, Resende MFS (2006) The genetic diversity of two Brazilian Vellozia (Velloziaceae) different patterns of spatial distribution and pollination biology. Ann Bot - London 97:585-592.

Freire UC (2000) Origem da própolis verde e preta produzida em Minas Gerais. PhD Dissertation. Universidade Federal de Viçosa, Viçosa.

Ghisalberti EL (1979) Propolis: a review. Bee World 60:59-84.

Giménez-Cassina B, Schmidt EM, Eberlin MN, Sawaya ACHF (2014) Phytochemical markers of different types of red propolis. Food Chem 146:174-180.

Grace J, San Jose J, Meir P, Miranda HS, Montes RA (2006) Productivity and carbon fluxes of tropical savannas. J Biogeogr 33:387-400.

Harborne JB, Greenham J, Williams Ca, Eagles J, Markham KR (1993) 10 Isoprenylated and $C$-methylated flavonoids from the leaves of 3 Vellozia species. Phytochemistry 34:219-226.

Havsteen B (1983) Flavonoids, a class of natural products of pharmacological potency. Biochem Pharmacol 32:1141-1148.

Hopkins RJ, van Dam NM, vanLoon JJA (2009) Role of glucosinolates in insect-plant relationships and multitrophic interactions. Ann Rev Entom 54:57-83.

Huang P, Nishi M, Zheng XZ, Lai MX, Naknishi T (1997) Triterpene acids from the barks of Illicium difengpi. Yао Хие Хие Вао 32, 704-707 (in Chinese).
Hussain AI, Anwar F, Nigam PS, Ashraf M, Gilani AH (2010) Seasonal variation in content, chemical composition and antimicrobial and cytotoxic activities of essential oils from four Mentha species. J. Sci Food Agr 90:1827-1836.

Ishida VFD, Negri G, Salatino A, Bandeira MFCL (2011) A new type of Brazilian propolis: prenylated benzophenones in propolis from Amazon and effects against cariogenic bacteria. Food Chem 125:966-972.

Jaubert GF (1926) Origin of the colour of beeswax and the composition of propolis. CR Hebd Acad Sci 184:1134-1136.

Jiménez-Pomárico A, Avila-Nuñez JL, Oliveros-Bastidas A, Márquez FR, Avendaño M, Uzcátegui D, MendozaBriceño FV, Dávila-Vera D, Rojas L.B, Aparicio R (2019) Chemical and morpho-functional aspects of the interaction between a Neotropical resin bug and a sticky plant. Rev Biol Trop 67:454-465.

Jorge R, Furtado NAJC, Sousa JPB, da Silva AA, Gregoria LE, Martins CHG, Soares AEE, Bastos JK, Cunha WR, Silva MLA (2008) Brazilian propolis: seasonal variation of the prenylated $p$-coumaric acids and antimicrobial activity. Pharm Biol 46:889-893.

Koo H, Rosalen PL, Cury JA, Park YK, Ikegaki M, Sattler A (1999) Effect of of Apis mellifera propolis from two Brazilian regions on caries development in desalivated rats. Caries Res 33:393-400.

Kortbeek RWJ, van der Gragt M, Bleeker PM (2018) Endogenous plant metabolites against insects. Eur Journal Plant Pathol 154:67-90.

Kumazawa S, Nakamura J, Murase M, Miyagawa M, Ahn M-R, Fukumoto S (2008) Plant origin of Okinawan propolis: honey bee behavior observation and phytochemical analysis. Naturwissenschaften 95:781-786.

Kuropatnicki AK, Szliszka E, Krol W (2013) Historical aspects of propolis research in modern times. Evid-Based Compl Alt 2013 (https://doi.org/10. 1155/2013/964149)

Lavina FC, Macedo EH, Sá GBL, Amaral ACF, Azevedo MMB, Domingos TFS, Vermelho AB, Carneiro CS, Rodrigues IA (2019) Brazilian stingless bee propolis and geopropolis: promising sources of biologically active compounds. Rev Bras Farmacogn 29:398-399.

Leonhardt SD., Zeilhofer S, Blüthgen N, Schmitt T (2010) Stingless bees use terpenes as olfactory cues to find resin sources. Chem Senses 35:603-611.

Lepsch IF, de Oliveira LA, Pinilla-Navarro A, Coe HHG (2014) Phytoliths from the rough leaves of two dicotyleconous species from the Brazilian cerrado biome and their occurrence in soils. In: H.H.G. Coe and M. Osterrieth (Eds.) Synthesis of some phytolith studies in South America (Brazil and Argentina). Nova Publishers, New York, pp. 75-89.

Lokvam J, Braddock JF (1999) Anti-bacterial function in the sexually dimorphic pollinator rewards of Clusia glandiflora (Clusiaceae). Oecologia 119:534-540. 
López BGC, Schmidt EM, Eberlin MN, Sawaya ACHF (2014) Phytochemical markers of different types of red propolis. Food Chem 146:174-180.

Machado CS, JB Mokochinski TO, Lira FCE, Oliveira de MV, Cardoso RG, Ferreira ACHF, Sawaya AG, Ferreira C, Pessoa O, Cuesta-Rubio MC, Monteiro MS, Campos de YR Torres 2016 Comparative study of chemical composition and biological activity of yellow, green, brown, and red Brazilian propolis EvidBased Compl and Alt 2016 (https://doi.org/10.1155/ 2016/6057650)

Madeira JA, Ribeiro KT, Fernandes GW (1998) Herbivory, tannins and sclerophylly in Chamaecrista linearifolia (Fabaceae) along an altitudinal gradient. Braz J Ecol 2:24-29.

Marcucci MR (1995) Propolis: chemical composition, biological properties and therapeutic activity. Apidologie 26:83-99.

Matsuda AH, Almeida-Muradian LB (2008) Validated method for the quantification of artepillin-C in Brazilian propolis. Phytochem Analysis 30:179-183.

Mayworm MAS, Fernandes-Silva CC, Salatino MLF, Salatino A (2015) A simple and inexpensive procedure for detection of a marker of Brazilian alecrim propolis. J Apicult Res 54:36-39.

MAS Mayworm CA Lima ACB Tomba CC FernandesSilva MLF Salatino A Salatino 2014 Does propolis contain tannins? Evid-Based Compl Alt 2014 (https://doi.org/10.1155/2014/613647)

Mayworm MAS, dos Santos AB, Melo-de-Pinna GFA, Salatino A, Salatino MLF, Demarco D (2017) Monoterpenes from the essential oil from Brazilian propolis affect seedling cellular elongation. Braz J Bot 40:609-615.

Moise AR, Bobiş O (2020) Baccharis dracunculifolia and Dalbergia ecastophyllum, main plant sources for bioactive properties in green and red Brazilian propolis. Plants 9 (https://doi.org/10.3390/plants9111619)

Mura A, Pusceddu M, Theodorou P, Angioni A, Floris I, Paxton RJ, Satta A (2020) Propolis consumption reduces Nosema ceranae infection of European honey bees (Apis mellifera). Insects 11124 (https:// doi.org/10.3390/insects11020124)

Nascimento EA, Chang R, Morais SAL, Pilo-Veloso D, Reis DC (2008) An easily detectable marker for the Baccharis dracunculifolia propolis. Rev Braz Pharmacog 18:379-386.

Negri G, Marcucci MC, Salatino A, Salatino MLF (2000) Comb and propolis waxes: triterpenoids in propolis waxes. J Apicult Res 29:86-88.

Negri G, Salatino MLF, Salatino A (2003a) 'Green propolis': unreported constituents and a novel compound from chloroform extracts. J Apicult Res 42:39-41.

Negri G, Salatino MLF, Salatino A (2003b) Unusual chemical composition of a sample of Brazilian propolis, as assessed by analysis of a chloroform extract. J Apicult Res 42:53-56.
Neilson EH, Goodger JQD, Woodrow IE, Moller BL (2013) Plant chemical defense: at what cost? Trends Plant Sci 185 (https://doi.org/10.1016/j. tplants.2013.01.001)

Nina N, Quispe C, Jimenez-Aspee F, Theoduloz C, Gimenez A, Schmeda-Hirschmann G (2016) Chemical profiling and antioxidant activity of Bolivian propolis. J Sci Food Agr 96:2142-2153.

Oliveira ACP, Shinobu ES, Longhini R, Franco SL, Svidzinski TIE (2006) Antifungal activity of propolis extract against yeasts isolated from onychomycosis lesions. Mem I Oswaldo Cruz 101:493-497.

Park YK, Alencar SM., Scamparina ARP, Aguiar SC (2002) Própolis produzida no sul do Brasil, Argentina e Uruguai: evidências fitoquímicas de sua origem vegetal. Cienc Rural 32:997-1003.

Park YK, Ikegaki M, Alencar SM (2000) Classificação das própolis brasileira a partir de suas características físico-químicas e propriedades biológicas. Mensagem Doce 58:2-7.

Piccinelli AL, Lotti C, Campone L, Cuesta-Rubio O, Fernandez MC, Rastrelli L (2011) Cuban and Brazilian red propolis: botanical origin and comparative analysis by high-performance liquid chromatography-photodiode array detection/electrospray ionization tandem mass spectrometry. $\mathrm{J}$ Agr Food Chem 59:6484-6491.

M Popova E Giannopoulou K Skalicka-Wozniak K Graikou J Widelski V Bankova H Kalofonos G Sivolapenki K Gawel-Beben B Antosiewicz I Chinou 2017 Characterization and biological evaluation of propolis from Poland Molecules 22 (https://doi.org/10.3390/molecules22071159)

Popova M, Trusheva B, Khismatullin R, Gavrilova N, Legotkina G, Lyapunov J, Bankova V (2013) The triple botanical origin of Russian propolis from the Perm region, its phenolic content and antimicrobial activity. Nat Prod Commun 8:617-620.

Prychid CJ, Rudall PJ, Gregory M (2003) Systematics and biology of silica bodies in monocotyledons. Bot Rev 69:377-440.

Przybylek I, Karpinski TM (2019) Antibacterial properties of propolis. Molecules 242047

Pusceddu M, Floris I, Mura A, Theodorou P, Cirotto G. Piluzza G, Bullita S, Angioni A, Satta A (2018) The effects of raw propolis on Varroa-infested honey bee (Apis mellifera) workers. Parasitol Res 117:3527- 3533 .

Regueira Neto MS, Tintino SR, da Silva ARP, Costa MD, Boligon AA, Matias EFF, Balbino VD, Menezes IRA, Coutinho HDM (2017) Seasonal variation of Brazilian red propolis: antibacterial activity, synergistic effect and phytochemical screening. Food Chem Toxicol 107:572-580.

Reinhard A, Janke M, von der Ohe W, Kempf M, Theuring C, Hartmann T, Schreier P, Beuerle T (2009) Feeding 
deterrence and detrimental effects of pyrrolizidine alkaloids fed to honey bees (Apis mellifera). J Chem Ecol 35:1086-1095.

Ribeiro VP, Arruda C, Aldana-Mejia JA, Candido ACBB, dos Santos RA, Magalhães LG, Bastos JK (2020) Brazilian southeast brown própolis: gas chromatography method development for its volatile oil analysis, its antimicrobial and leishmanicidal activities evaluation. Phytochem Anal 32:404-441.

Ribeiro SP, Braga AO, Silva CHL, Fernandes GW (1999) Leaf polyphenols in Brazilian Melastomataceae: sclerophylly, habitats, and insect herbivores. Biotropica 5:137-146.

Righi AA, Thiago RA, Negri G, Marques LM, Breyer H, Salatino A (2011) Brazilian red propolis: unreported substances, antioxidant and antimicrobial activities. J Sci Food Agr 91:2363-2370.

Righi AA, Negri G, Salatino A (2013) Comparative chemistry of propolis from eight Brazilian localities. Evid-Based Compl Alt 2013 (https://doi.org/ 10.1155/2013/267878)

Salas A, Mercado MI, Zampini IC, Ponessa GI, Isla MI (2016) Determination of botanical origin of propolis from Monte region of Argentina by histological and chemical methods. Nat Prod Commun 11:627-630.

Salatino A. 1993. Chemical ecology and the theory of oligotrophic scleromorphism. An Acad Bras Cienc 65:1-13.

Salatino A, Fernandes-Silva CC, Righi AA, Salatino MLF (2011) Propolis research and chemistry of plant products. Nat Prod Rep 29:925-936.

Salatino A, Salatino MLF (2017) Why do honeybees exploit so few plant species as propolis sources? MOJ Food Process Technols 4 (https://doi.org/10. 15406/mojfpt.2017.04.00107)

Salatino A, Salatino MLF (2018) Brazilian red propolis: legitimate name of the plant resin source MOJ Food Process Technols 6 (https://doi.org/10.15406/ mojfpt.2018.06.00139)

Salatino A, Teixeira EW, Negri G, Message D (2005) Origin and chemical variation of Brazilian propolis. Evid-Based Compl Alt 2:33-38.

Salminen JP, Karonen M (2011) Chemical ecology of tannins and other phenolics: we need a change in approach. Funct Ecol 25:325-338.

Sammataro D, Cicero JM (2010) Functional morphology of the honey stomach wall of the European honey bee (Hymenoptera: Apidae). Ann Entomol Soc Amer 6:979-987.

Santos MG, Oliveira MT, Figueiredo KV, Falcão HM, Arruda ECP, Almeida-Cortez J, Sampaio EVSB, Ometto JPHB, Menezes RSC, Oliveira AFM, Pompelli M, Antonino ACD (2014) Caatinga, the Brazilian dry tropical forest: can it tolerate climate changes? Theor Exp Plant Phys 26:83-99.

Sarker SD, Nahar L (2017) Progress in the chemistry of naturally occurring coumarins. Prog Ch Org Nat Prod 106:241-304.
Sen T, Samanta SK (2015) Medicinal plants, human health and biodiversity: a broad review. Adv Biochem Eng Biot 147:59-110.

Sforcin J (2016) Biological properties and therapeutic applications of propolis. Phytother Res 30:894-905.

Shuaib M, Ali A, Ali M, Panda B, Ahmad MI (2013) Antibacterial activity of resin rich plant extracts. J Pharm Bioallied Sci 5:265-269.

Silva BB, Rosalen PL, Cury JA, Ikegaki M, Souza VC, Esteves A, Alencar SM (2008) Chemical composition and botanical origin of red propolis, a new type of Brazilian propolis. Evid-Based Compl Alt 5:313-316.

Silveira MAD, Jong DD, Berreta AA, Galvão EBS, Ribeiro JC, Cerqueira-Silva T, Amorim TC, da Conceição LFMR, Gomes MACH, San Martin RL, Silva MO, Lírio M, Moreno L, Sampaio JCM, Mendonça R, Ultchak SS, Amorim FS, Ramos JGR, Batista PBP, da Guarda SNF, Mendes AVA, Passos RH for the BeeCovid Team (2021) Brazilian green propolis (EPP-AF®) as an adjunct treatment for COVID-19 patients: a randomized, controlled clinical trial. Biomed 138 (https://doi.org/10.1016/j. biopha.2021.111526)

Simone-Finstrom M, Gardner J, Spivak M (2010) Tactile learning in resin foraging honeybees. Behav Ecol Sociobiol 64:1609-1617.

Simone-Finstrom M, Spivak M (2010) Propolis and bee health: the natural history and significance of resin use by honey bees. Apidologie 41:295-311.

Simone-Finstrom MD, Spivak M (2012) Increased resin collection after parasite challenge: a case of selfmedication in honey bees? PloS ONE 7:17-21.

Souza EA, Zaluski R, Veita N, Orsi RO (2016) Effects of seasonal variations and collection methods on the mineral composition of propolis from Apis mellifera Linnaeus beehives. Braz. J. Biol. 76:396-401.

Souza MC, Franco AC, Haridasan M, Rossatto DR, De Araujo JF, Morellato LPC, Habermann G (2015) The length of the dry season may be associated with leaf scleromorphism in cerrado plants. An Acad Bras Cienc 87:1691-1699.

Tazawa S, Arai T, Hotta S, Mitsui T, Nozaki H, Ichihara K (2016) Discovery of a novel diterpene in brown propolis from the state of Paraná, Brazil. Nat Prod Commun 11:201-205.

Teixeira EW, Message D, Negri G, Salatino A (2006) Bauer-7-em-3 $\beta$-yl acetate: a major constituent of unusual samples of Brazilian propolis. Quim Nova 29:245-246.

Teixeira EW, Negri G, Meira RMSA, Message D, Salatino A (2005) Plant origin of green propolis: bee behavior, plant anatomy and chemistry. Evid-Based Compl Alt 2:85-92.

Teixeira EW, Message D, Negri G, Salatino A, Stringheta PC (2010) Seasonal variation, chemical composition and antioxidant activity of Brazilian propolis samples. Evid-Based Compl Alt 7:307-315. 
Tomás-Barberán FA, García-Viguera C, Vit-Olivier P, Ferreres F, Tomás-Lorente F (1993) Phytochemical evidence for the botanical origin of tropical propolis from Venezuela. Phytochemistry 34:191-196.

Tomizawa M, Casida JE (2005) Neonicotinoid insecticide toxicology: mechanisms of selective action. Annu Rev Pharmacol 45:247-268.

VC Toreti HH Sato M Pastore YK Park 2013 Recent progress of propolis for its biological and chemical composition and its botanical origin Evid-Based Compl Alt 2013 (https://doi.org/10.1155/2013/ 697390)

Tran VH, Duke RK, Abu-Mellal A, Duke CC (2012) Propolis with high flavonoid content collected by honey bees from Acacia paradoxa. Phytochemistry 81:126-132.

R Tsao CJ Peterson JR Coats 2002 Glucosinolate breakdown products as insect fumigants and their effect on carbon dioxide emission of insects BMC Ecol 2 5 (https://doi.org/10.1186/1472-6785-2-5)

Trusheva B, Popova M, Naydenski H, Tsvetkova V, Rodrigues JG, Bankova V (2004) New polyisoprenylated benzophenones from Venezuelan propolis. Fitoterapia 75:683-689.

Trusheva B, Todorov I, Ninova M, Najdenski H, Daneshmand A, Bankova V (2010) Antibacterial mono- and sesquiterpene esters of benzoic acids from Iranian propolis. Cham Central J 4; (http:// journal.chemistrycentral.com/content/4/1/8).

Valencia D, Aalday E, Robles-Zepeda R, Garibay-Escobar A, Galvez-Ruiz JC, Salas-Reves M, Jimenez-Estrada M, Velazquez-Contreras E, Hernandez J, Velazquez C (2012) Seasonal effects on chemical composition and biological activities of Sonoran propolis. Food Chem 131:645-651.

van Ohlen M, Herfurth AM, Kerbstadt H, Wittstock U (2016) Cyanide detoxification in an insect herbivore: molecular identification of $\beta$-cyanoalanine synthases from Pieris rapae. Insect Biochem Molec 70:99-110.

Veitch NC (2007) Isoflavonoids of the Leguminosae. Nat Prod Rep 24:417-464.
Villanueva VR, Barbier M, Gonnet M, Lavie P (1970) Les flavonoids de la propolis. Isolement d'une nouvelle substance bactériostatique: la pinocembrine (dihydroxy-5,7 flavanone). Ann I Pasteur Paris 118:84-87.

Villanueva VR, Bogdanovsky D, Barbier M, Gonnet M, Lavie P (1964) Sur l'isolament et l'identification de la 3,5,7 trihydroxy flavone (Galangine) a partir de la propolis. Ann I Pasteur Paris 106:292-302.

Xavier JA, Valentim IB, Camatari FOS, Almeida AMM, Goulart HF, Ferro JNS, Barreto EO, Cavalcanti BC, Bottoli CBG, Goulart MOF (2017) Polyphenol profile by UHPLC-MS/MS, anti-glycation, antioxidant and cytotoxic activities of several samples of propolis from the northeastern semi-arid region of Brazil. Pharm Biol 55:1884-1893.

War AR, Taggar GK, Hussain B, Taggar MS, Nair RM, Sharma HC (2018) Plant defence against herbivory and insect adaptations. AoB PLANTS 10 (https:// doi.org/10.1093/aobpla/ply037)

MB Wilson M Spivak AD Hegeman A Rendahl JD Cohen 2013 Metabolomics reveals the origins of antimicrobial plant resins collected by honey bees PLoS ONE 8 (https://doi.org/10.1371/journal.pone. 077512)

Worldatlas. 2018. Which crops and plants are pollinated by honey bees? https://www.worldatlas.com/articles/ which-crops-plants-are-pollinated-by-honey-bees. html; Accessed August 202020.

Zabaiou N, Fouache A, Trousson A, Baron S, Zellagui A, Lahouel M, Lobaccaro JMA (2017) Biological properties of propolis extracts: something new from an ancient product. Chem Phys Lipids. 207:214-222.

Zagrobelny M, de Castro ECP, Moller BL, Bak S (2018) Cyanogenesis in arthropods: from chemical warfare to nuptial gifts. Insects 9 (https://doi.org/10.3390/ insects900051)

Publisher's Note Springer Nature remains neutral with regard to jurisdictional claims in published maps and institutional affiliations. 